\title{
The Epidemiology of Vascular Dementia
}

\author{
Demet Ozbabalık ${ }^{1}$, Didem Arslantaş ${ }^{1}$ and Nese Tuncer Elmac1 ${ }^{3}$ \\ ${ }^{1}$ Eskisehir Osmangazi University, Medical Faculty, \\ Department of Neurology, Eskisehir, \\ ${ }^{2}$ Marmara University, Medical Faculty, \\ Department of Neurology, Istanbul, \\ ${ }^{3}$ Eskisehir Osmangazi University, Medical Faculty, \\ Department of Public Health, Eskisehir, \\ Turkey
}

\section{Introduction}

Average life expectancy in the world is getting longer in the developing countries as well as developed countries. This means that we will encounter some of the diseases more than diseases which are only seen in elderly, in the coming years. Dementia is one of the most important health problems of the elderly population today, up to the developed countries is seen as a major threat in developing countries. WHO projections suggest that by 2025 , about three-quarters of the estimated 1.2 billion people aged 60 years and older will reside in developing countries (1). Thus, by 2040, if growth in the older population continues, $71 \%$ of $81 \cdot 1$ million dementia cases will be in the developing world (Figure 1) (2).

Epidemiology is the study of health-event patterns in a society (3). It is the cornerstone method of public health research, and helps inform evidence-based medicine for identifying risk factors for disease and determining optimal treatment approaches to clinical practice and for preventive medicine. Epidemiologic measures are named as two types; incidence and prevalence. Whereas incidence deals with what is new, prevalence deals with what exists. By definition, prevalence is the number of cases of a given disease that exists in a defined population at a specified time. Incidence represents new event.

Dementia is actually a syndrome. It may be caused by various underlying diseases, each characterized by specific clinical features and neuropathology. Alzheimer disease (AD) which is a neurodegenerative is the most prevalent cause of dementia. The neuropathology of disease include in neuritic plaques and neurofibrillary tangle in the brain. Vascular dementia (VaD), describing impairments in cognitive function caused by problems in cerebral or cardiac blood vessels, is the second most common cause of dementia after Alzheimer disease in the aging population (Figure 2) (4). It comprises 10-20\% of all dementia. A meta-analysis of the European studies on incidence of dementia showed that VaD constitute $17.6 \%$ of all dementia (5). In Europe and North America, $\mathrm{AD}$ is more common than $\mathrm{VaD}$ in a 2:1 ratio; in contrast in Japan and China $\mathrm{VaD}$ accounts for almost $50 \%$ of all dementia $(6,13)$.

Vascular dementia is a complex disease and a common complication resulting from a blocked blood vessel causing a stroke. The most common mechanisms underlying VaD are 
multiple large-vessel infarcts, a single strategically placed infarct (angular gyrus, thalamus, basal forebrain, posterior cerebral artery or anterior cerebral artery), multiple basal ganglia and white matter lacunes, or extensive periventricular white-matter lesions. The most commonly encountered subtype of $\mathrm{VaD}$ is extensive periventricular white-matter lesions. Multiple large vessel infarcts and others follow up them (14).

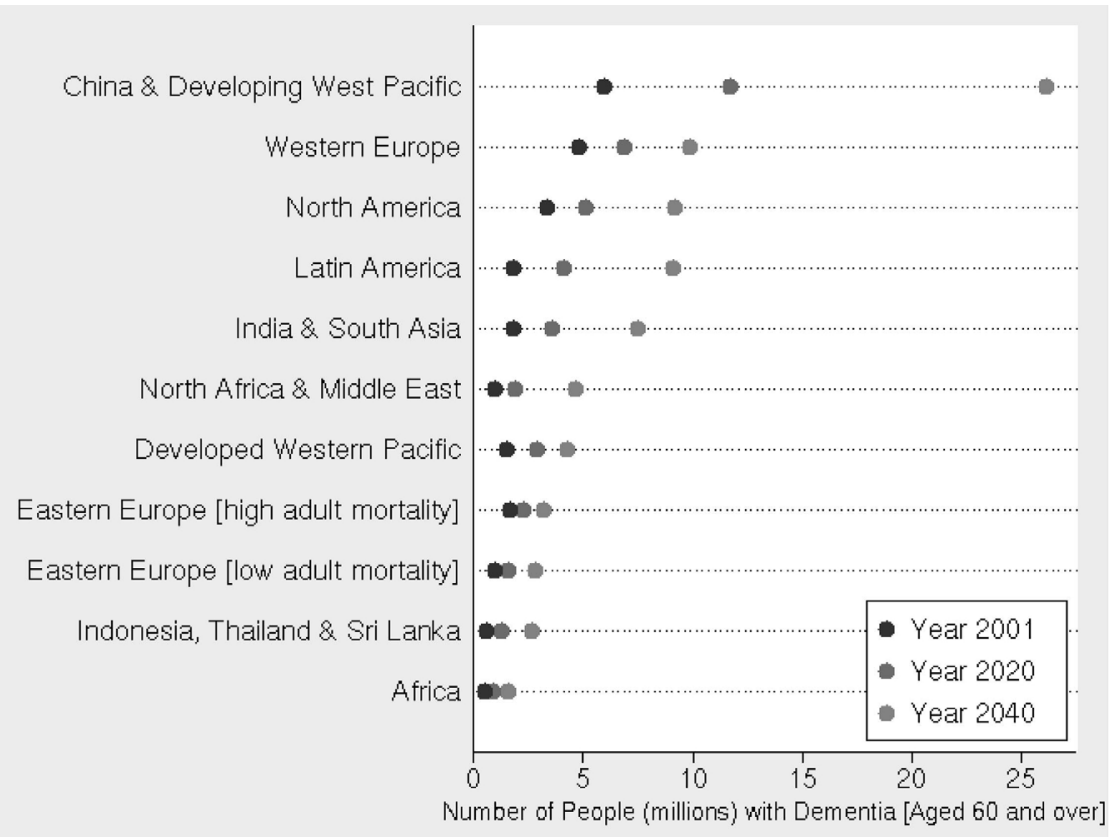

Fig. 1. Dementia prevalence 2001, 2020, 2040 by WHO Region Source: Ferri et al. (2005).

Vascular dementia is historically reflected by the diagnoses of "dementia with stroke" or "multi-infarct dementia," although these terms have been replaced with the broader concepts of vascular dementia and vascular cognitive impairment, recognizing the contribution to dementia of all vascular disease. Pathological findings have shown that much dementia cannot be attributed to a single underlying cause but arises from a combination of factors among which cerebrovascular disease, including infarct and haemorrhage, is an important contributor.

Although the incidence and prevalence of dementia are increasing, determining the incidence and prevalence of dementia is difficult (15-20).

Even with the difficulties of detecting and defining to prevalence and incidence in the population, it is clear that dementia causes a substantial burden on societies. There is an urgent need to develop preventive strategies and to identify of modifiable risk factors about each type of dementia. Newer imaging techniques and neuropsychological test batteries provide an opportunity to identify subclinical manifestations of "dementias" that can be limited to the risk factors and subsequent clinical disease. Problems with diagnostic inaccuracy and insidious disease onset influence results of the epidemiologic studies (21). 


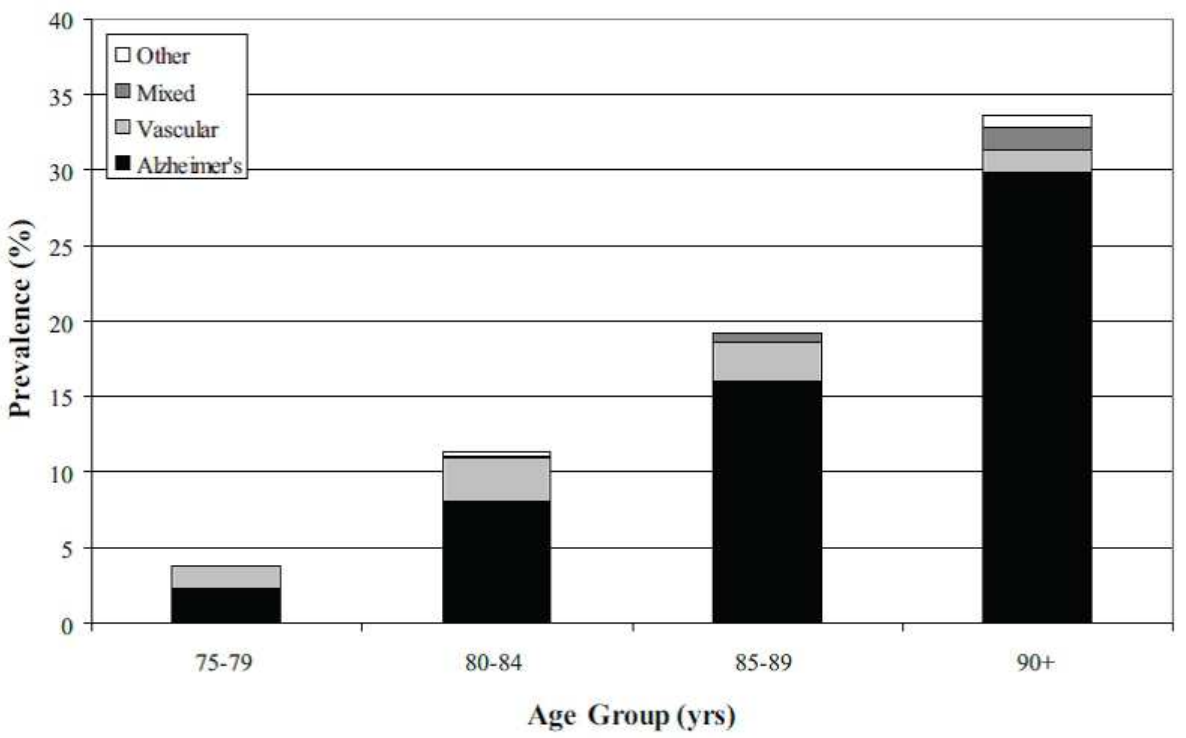

Fig. 2. Prevalence of dementia subtypes Data from the Cambridge City Over-75s Cohort Study (CC75C).

Epidemiologic studies of $\mathrm{VaD}$ have been also affected by variations in the definition of the disorders, the clinical criteria used and the methods. Analysis of data from 12 centres for which imaging findings were available indicates that $26 \%$ of cases of dementia fulfilled the US National Institute of Neurological Disorders and Stroke and Association Internationale pour la Recherché et l'Enseignement en Neurosciences (NINDS-AIREN) criteria for VaD $(22,23)$.

\section{Prevalence and incidence}

Prevalence estimates vary highly between studies because of methodological and geographical differences (Table 1) (24). However, the prevalence of $\mathrm{VaD}$ ranges from one to four percent in people over the age of 65 and seems to be higher in China and Japan than in Europe and North America. While the rate is $1.5 \%$ in Western countries and in Japan is approximately $2.2 \%$. In Japan, vascular dementia accounts for $50 \%$ of all dementias that occur in individuals older than 65 years. In Europe, vascular dementia and mixed dementia account for approximately $20 \%$ and $40 \%$ of cases, respectively (25-28).

In 2000, prevalence data from 11 European population based studies were pooled to obtain stable estimates of prevalence of dementia in the elderly (>65 years). Age standardised prevalence was $6.4 \%$ for dementia (all causes), and $1.6 \%$ for $\mathrm{VaD}(29)$. In clinical studies, the prevalence of $\mathrm{VaD}$ ranges from $4.4 \%$ and $39 \%$, its incidence from 0.42 to 2.65 , with doubling every 5 years in western memory clinical and population based series. In Asia, a number of studies on the prevalence of dementia have been published in Chinese, yielding varied results. By comparison with these studies that reported a prevalence range of $\mathrm{VaD}$ as $0.2 \%$ to $2.7 \%$, respectively for those aged 60 years and older (30). 
Data suggests that the annual incidence of $\mathrm{VaD}$ may range from 20-40 per 100000 between persons 60-69 years old to 200-700 per 100.000 in persons over age 80 .

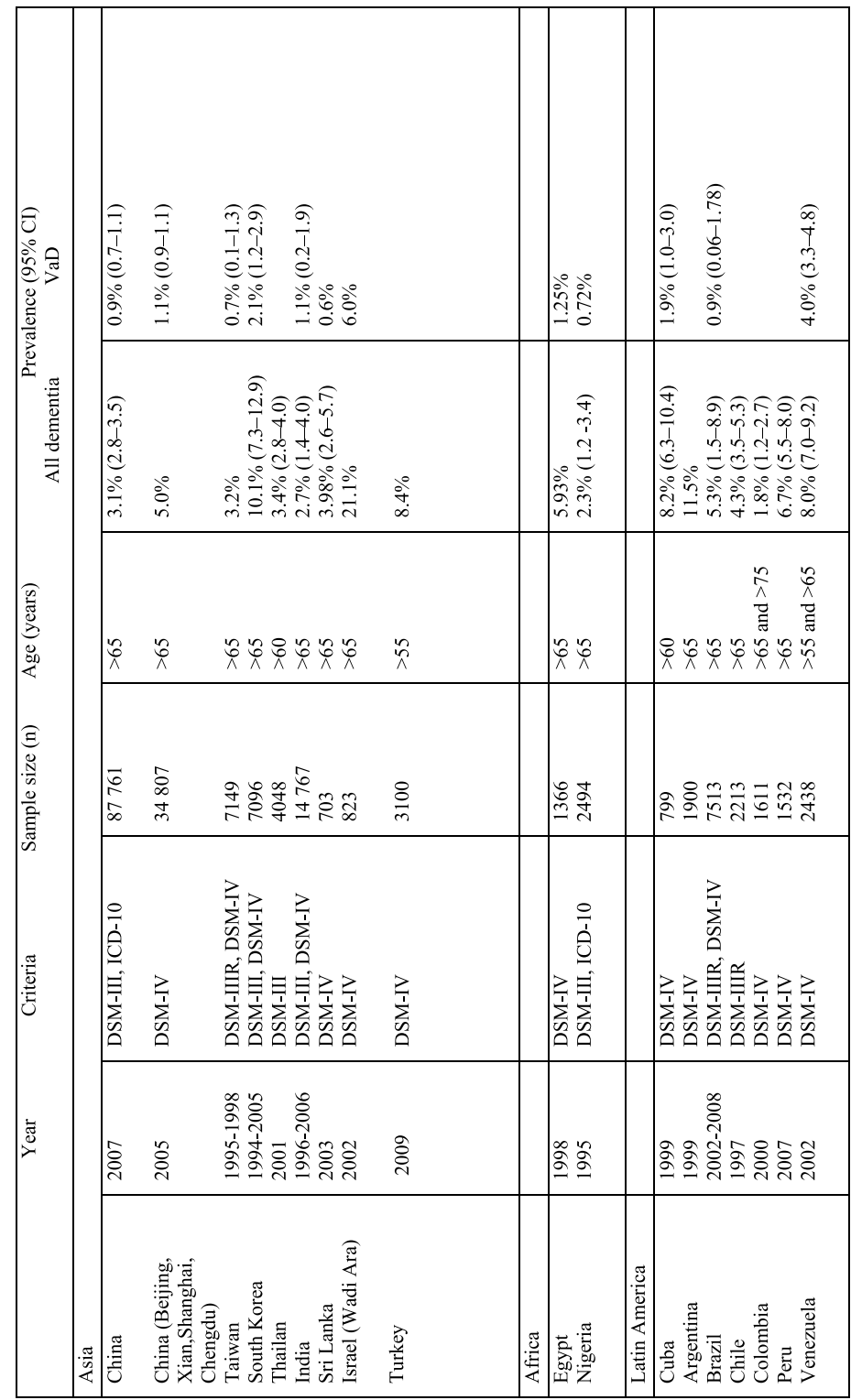

Table; Brayne C, Cambridge City Over-75s Cohort Cc75c Study Neuropathology Collaboration.

Neuropathological correlates of dementia in over-80-year-old brain donors from the population-based Cambridge city over-75s cohort (CC75C) study. J Alzheimers Dis. 2009 ( The Turkish data was added).

Table 1. 


\section{Age and gender}

Studies show that the occurrence of $\mathrm{VaD}$ exponentially increases with age from 65 to 85 years. The prevalence of dementia of all causes increases between the seventh and tenth decade from 0.8 to $28.5 \%$ that of vascular dementia (VD) (15.8\% of total) from 0.3 to $5.2 \%$ or from 0.2 to $16 \%$ over age 80 . In 2030, nearly 70 million patients with dementia is expected in 65 and older populations, without any substantial difference between men and women. Under eighty-five years of age the prevalence of $\mathrm{VaD}$ was higher in men compared to women and thereafter the prevalence was higher in women (29). In a longitudinal community survey of Japanese American men (Honolulu Asia Aging Study), 23\% of vascular dementia was attributed. to large-vessel, $50 \%$ to small-vessel, and $16 \%$ to mixedvessel disease (31).

The age-standardized prevalence of $\mathrm{VaD}$ was $1.6 \%$ and also increased with age. However, contrary to $\mathrm{AD}$, the difference in prevalence between men and women was age dependent. This finding might also be attributed to differences in survival between men and women. However, it may also reflect changes in incidence pattern.

\section{Variation across region}

There are differences amongst cultural, demographic and ethnic variability in incidence and prevalence studies. The proportion of $\mathrm{AD}$ and $\mathrm{VaD}$ dementia was different from that in Europe and other Asian countries. For example, VD tends to be more common than AD in Japan and Russia (31-32). Even, a marked geographical dissociation in Europe between the north and south, linked to differences in vascular risk factors has been proposed to account for the higher incidence rates in the oldest-old of north-western countries (Finland, Sweden, Denmark, the Netherlands, and the United Kingdom) compared to southern countries (France and Spain). This difference is further supported by north-South regional findings of differences in MRI-detected white matter lesion (WML) pathology. Greater WML pathology linked to progression of dementia has been observed in southern Europe relative to northern and central European countries $(33,35)$.

Few studies reported the differences in the distribution of dementia subtypes between rural and urban areas. Interestingly, they found that there was a significantly higher prevalence of Alzheimer disease in the rural area than the urban area. And on the contrary, there was a higher prevalence of vascular dementia in the urban area than the rural area. It may be owing to the differences in education levels, socioeconomic status, obesity and body mass index, diet, and life style between the two areas. If the future studies continue to report the higher prevalence of vascular dementia in urban areas, it means that there will be increased demands on healthcare system particularly among urban populations (36-40).

\section{Family history and genetic}

Dementia risk can increase two- to four-fold among individuals who have at least one first degree relative with dementia. Genetic factors play an important role in the aetiology of $\mathrm{VaD}$. However, there is less epidemiological evidence for a genetic component of risk factors of $\mathrm{VaD}$ like cardio embolic stroke. Two known genetic disease can be thought that $\mathrm{VaD}$ have genetic characteristics. These are cerebral autosomal dominant arteriopathy with subcortical 
infarcts and leucoencephalopathy (CADASIL: a subcortical small vessel disease accompanied by lacunars' strokes, migraine, and dementia) and hereditary cerebral haemorrhage with amyloidosis- Dutch type (HCHWA-D) (41).

The CADASIL condition is a heritable small-vessel disease caused by mutations in NOTCH3 gene which is normally expressed in vascular smooth muscle cells and pericytes (including those of the cerebral vasculature) and that encodes a cell-surface receptor, which has a role in arterial development and is expressed on vascular smooth-muscle cells. About $95 \%$ of patients have missense mutations that cluster in exons 3 , but the pathogenic mechanism is still unknown. With regard to HCHWA-D (a syndrome of primarily hemorrhagic strokes and dementia), it is caused by a mutation in the gene for amyloid precursor protein (APP) that causes abnormal deposition of amyloid in the walls of leptomeningeal arteries and cortical arterioles, it is known as cerebral amyloid angiopathy [CAA] (42).

The studies using the candidate gene approaches has identified a number of genetic variants possibly involved in risk factor development. They can contribute to conventional risk factors such as hypertension, diabetes, or homocysteine concentrations. Recently, APO E4 was studied in $\mathrm{VaD}$ after $\mathrm{AD}$ as risk factors. As authors, VaD risk also increases with the number of alleles: homozygous carriers are at a greater risk than heterozygous carries or those who do not carry the E4 variant $(43,44)$.

A study showed that MAPT (microtubule-associated protein tau) was associated with VaD and since MAPT is a gene playing an important role in AD. Moreover, G allele of rs 1467967 is the risk allele, which is the major allele in Chinese population (45).

\section{Hypertention and other vascular risk factors}

Mid-life hypertension (high blood pressure) has been associated with impaired cognitive function even in otherwise healthy individuals (46). Traditionally $\mathrm{VaD}$ has been considered affected by hypertension and the alleviation of it. In a Japan study, the age- and sex-adjusted incidence of $\mathrm{VaD}$ significantly increased with elevated late-life blood pressure levels whereas no such association was observed for Alzheimer disease. The current meta-analysis highlights the potential importance of rigorous treatment of hypertension as a key measure to help prevent the development of $\mathrm{VaD}(47)$.

Except hypertension, histories of diabetes, metabolic syndrome, hyperlipidemia, myocardial infarction/cardiac decomposition, heavy smoking, obesity and a history of stroke are other risk factors for VaD. The Cardiovascular Health Cognition Study developed a late-life dementia risk index that included older age, worse cognitive test performance, lower body mass index (BMI), APOE _4 allele, MRI findings of white matter disease or ventricular enlargement, internal carotid artery thickening on ultrasound, history of bypass surgery, slower physical performance, and lack of alcohol consumption (48).

\section{Lifestyle}

Risk finding for alcohol is not consistent. Alcohol has been found to have a protective effect in moderate drinkers with a five-fold increase in dementia in both abstainers and those who drink heavily. A study found a link between increasing alcohol consumption and VaD (49). 
In some studies alcohol and smoking are neither strongly protective nor predictive (50). In some studies were informed that high educational attainment, eating fish or shellfish, physical exercise, use of supplementary antioxidants like beta-carotene, omega-3, Vitamins E and C, use of Vitamin B12, Mediterranean diet might be potential protective factors for $\operatorname{VaD}(51,53)$.

\section{Conclusion remarks}

1. Vascular dementia $(\mathrm{VaD})$ is the second most common cause of dementia after Alzheimer disease in the aging population.

2. Prevalence estimates vary highly between studies because of methodological and geographical differences.

3. Prevalence rate is $1.5 \%$ in Western countries and in Japan is approximately $2.2 \%$.

4. Annual incidence of $\mathrm{VaD}$ may range from 20-40 per 100000 between persons $60-69$ years old to 200-700 per 100.000 in persons over age 80 .

5. There are differences amongst cultural, demographic and ethnic variability in incidence and prevalence studies.

6. Sex patterns remain unclear for prevalence and incidence.

7. Dementia risk can increase two- to four-fold among individuals who have at least one first degree relative with dementia.

8. Hypertension, histories of diabetes, metabolic syndrome, hyperlipidemia, myocardial infarction/cardiac decomposition, heavy smoking, obesity and a history of stroke are other risk factors for $\mathrm{VaD}$.

9. Finally, about epidemiology of $\mathrm{VaD}$ is not clear as well as $\mathrm{AD}$. We need more studies in the world.

\section{References}

[1] WHO. Active Ageing: a policy framework, 2002 Health Report. Geneva: world health organization, 2002.

[2] Ferri CP, Prince M, Brayne c. Global prevalence of dementia: a delphi consensus study. Lancet 2005; 366: 2112-17

[3] Rothman K, Greenland S. Modern epidemiology, 2nd ed. Philadelphia: LippincottRaven, 1998

[4] Brayne C, Richardson K, Matthews FE, Fleming J, Hunter S, Xuereb JH, Paykel E,Mukaetova-Ladinska EB, Huppert FA, O'Sullivan A, Dening T; Cambridge City Over-75s Cohort Cc75c Study Neuropathology Collaboration. Neuropathological correlates of dementia in over-80-year-old brain donors from the population-based Cambridge city over-75s cohort (CC75C) study. J Alzheimers Dis. 2009;18(3):645-58.

[5] Rocca WA, Hofman A, Brayne C. Frequency and distribution of alzheimer's disease in Europe: a collaborative study of 1980-1990 prevalence findings. The EURODEM prevalence research group. Ann neurol 1991; 30: 381-90

[6] From the Centers for Disease Control and Prevention. Public health and aging: trends in aging--United States and worldwide. JAMA. 2003,19;289(11):1371-3.

[7] Wimo A, Winblad B, Agu“ Ero-Torres H, Von Strauss E. The magnitude of dementia occurrence in the world. Alzheimer Dis Assoc Disord 2003; 17: 63-67. 
[8] Yamada t, Hattori H, Miura A, Prevalence of Alzheimer's disease, vascular dementia and dementia with lewy bodies in a japanese population. Psychiatry Clin Neurosci. 2001;55:21-25.

[9] Dong MJ, Peng B, Lin XT, Zhao J, Yan-Rong Zhou YR, Wang RH. The prevalence of dementia in the people's republic of china: a systematic analysis of 1980-2004 studies. Age and Ageing 2007; 36: 619-624.

[10] Gorelick PB, Roman G, Mangone CA (1994) Vascular Dementia. In: Gorelick PB, Alter MA (eds) handbook of Neuroepidemiology. Mecel Dekker, New York, pp 197-214

[11] Hachinski VC, Lassen MA, Marshall J Multi-infarct dementia. A cause of mental deterioration in elderly. Lancet 1974,2:207-210

[12] Roman GC, Sachdev P, Royall DR, Vascular cognitive disorder: a new diagnostic category updating vascular cognitive impairment and vascular dementia. Neurol Sci, 2004, 226:81-87

[13] Sachdev P, Vascular cognitive disorder. Int J Geriatr Psychiatry, 1999, 14: 402-403

[14] Nizam Z, Hyer L, Vascular cognitive impairment: perspective and review The Journal of Psychiatry , 2007 325-325

[15] O'brien JT, Erkinjuntti T, Reisberg B , Vascular cognitive impairment. Lancet Neurol, 2003, 2:89-98

[16] Cagnin A, Battistin 1 (2007) vascular dementia. In: Readerer Battistin (ed) handbook of neurochemistry and molecular neurobiology. Springer-Verlag, 253-265

[17] Cowan LD., Leviton A., Dammann O. New Research Directions In neuroepidemiology. Epidemiology review, 2000, 22: 18-23.

[18] Dartigues JF., Letenneur, L., Joly, P., Helmer, C., Orgogozo,J. Age specific risk of dementia according to gender, education and wine consumption. Neurobiology of Aging, 2000, 21: 64.

[19] Fratiglioni L, De Ronchi D, Agüero-Torres H. Worldwide prevalence and incidence of dementia. Drugs Aging 1999;15:365-75.

[20] Fratiglioni L, Roccaw. Epidemiology of dementia. In: Boller F, Cappa SF, editors. Handbook of Neuropsychology: Aging and dementia. Amsterdam: elsevier sc publ; 2001. P. 193-215.

[21] Fratiglioni L, Launer LJ, Andersen K, Breteler MM, Copeland JR, Dartigues JF, Incidence of dementia and major subtypes in Europe: a collaborative study of population-based cohorts. Neurologic diseases in the elderly research group. Neurology 2000;54(suppl 5):s10-5.

[22] Román GC. Vascular dementia revisited: diagnosis, pathogenesis, treatment, and prevention. Med Clin North Am. 2002;86:477-499.

[23] Roman GC, Tatemichi TK, Erkinjuntti T, Vascular dementia: diagnostic criteria for research studies: report of the NINDSAIREN international workshop. Neurology 1993; 43: 250-60

[24] Zhang ZX, Zahner GE, Roman GC. Dementia subtypes in China: Prevalence in Beijing, Xian, Shanghai, and Shengdu. Arch Neurol 2005; 62: 447-53

[25] Yang B. Meta prevalence estimates: generating combined prevalence estimates from separate population surveys. Centre for epidemiology and research, nsw department of health (australia). Http://www.health.nsw.gov.au

[26] Kalaria RN, Maestre GE, Arizaga R, Friedland RP, Galasko D, Hall K, Luchsinger JA, Ogunniyi A, Perry EK, Potocnik F, Prince M, Stewart R, Wimo A, Zhang ZX, 
Antuono P; World Federation of Neurology Dementia Research Group. Alzheimer's disease and vascular dementia in developing countries: prevalence, management,and risk factors. Lancet Neurol. 2008 Sep;7(9):812-26

[27] Plassman BL, Langa KM, Fisher GG, Heeringa SG, Weir DR, Ofstedal MB, Burke JR,Hurd MD, Potter GG, Rodgers WL, Steffens DC, Willis RJ, Wallace RB. Prevalence of dementia in the United States: the aging, demographics, and memory study.Neuroepidemiology. 2007;29(1-2):125-32.

[28] Lobo A, Launer LJ, Fratiglioni L, Andersen K, Di Carlo A, Breteler MM, Copeland JR, Dartigues JF, Jagger C, Martinez-Lage J, Soininen H, Hofman A. Prevalence of dementia and major subtypes in Europe: A collaborative study of population-based cohorts. Neurologic Diseases in the Elderly Research Group. Neurology. 2000;54(11 Suppl 5):S4-9

[29] Dong MJ, Peng B, Lin XT, Zhao J, Zhou YR, Wang RH. The prevalence of dementia in the People's Republic of China: a systematic analysis of 1980-2004 studies. Age Ageing. 2007 Nov;36(6):619-24.

[30] Harvey RJ, Skelton-Robinson M, Rossor MN. The prevalence and causes of dementia in people under the age of 65 years. J Neurol Neurosurg Psychiatry. 2003 ;74(9):1206-9.

[31] Launer LJ, Ross GW, Petrovitch H, Masaki K, Foley D, White LR, Havlik RJ.Midlife blood pressure and dementia: the Honolulu-Asia aging study. Neurobiol Aging. 2000;21(1):49-55

[32] Karasawa A, Homma A. Recent changes in the prevalence of dementia in the Tokyo Metropolis. In: Hasegawa K, Homma A, eds. Psychogeriatrics:Bbiomedical and Social Advances, Vol. 1, Amsterdam Excerpta Medica 1990; 24-9. 37.

[33] Ikeda M, Hokoishi K, Maki N, Nebu A, Tachibana N, Komori K, Shigenobu K, Fukuhara R, Tanabe H. Increased prevalence of vascular dementia in Japan: a community-based epidemiological study. Neurology. 2001 Sep 11;57(5):839-44.

[34] Fratiglioni L, Launer LJ, Andersen K, Breteler MM, Copeland JR, Dartigues JF, Lobo A, Martinez-Lage J, Soininen H, Hofman A. Incidence of dementia and major subtypes in Europe: A collaborative study of population-based cohorts. Neurologic Diseases in the Elderly Research Group. Neurology. 2000;54(11 Suppl 5):S10-5.

[35] Launer LJ, Berger K, Breteler MM, Dufouil C, Fuhrer R, Giampaoli S, Nilsson LG, Pajak A, de Ridder M, van Dijk EJ, Sans S, Schmidt R, Hofman A. Regional variability in the prevalence of cerebral white matter lesions: an MRI study in 9 European countries (CASCADE). Neuroepidemiology. 2006;26(1):23-9.

[36] Baiyewu O, Unverzagt FW, Ogunniyi A, Hall KS, Gureje O, Gao S, Lane KA, Hendrie HC. Cognitive impairment in community-dwelling older Nigerians: clinical correlates and stability of diagnosis. Eur J Neurol. 2002 Nov;9(6):573-80.

[37] Xu G, Meyer JS, Huang Y, Chen G, Chowdhury M, Quach M. Cross-cultural comparison of mild cognitive impairment between China and USA. Curr Alzheimer Res. 2004 Feb;1(1):55-61.

[38] Das SK, Bose P, Biswas A, Dutt A, Banerjee TK, Hazra AM, Raut DK, Chaudhuri A, Roy T. An epidemiologic study of mild cognitive impairment in Kolkata, India. Neurology. 2007 Jun 5;68(23):2019-26

[39] Lopes MA, Hototian SR, Bustamante SE, Azevedo D, Tatsch M, Bazzarella MC,Litvoc J, Bottino CM. Prevalence of cognitive and functional impairment in a community sample in Ribeirão Preto, Brazil. Int J Geriatr Psychiatry. 2007 Aug;22(8):770-6. 
[40] Hototian SR, Lopes MA, Azevedo D, Tatsch M, Bazzarella MC, Bustamante SE, Litvoc J, Bottino CM. Prevalence of cognitive and functional impairment in acommunity sample from São Paulo, Brazil. Dement Geriatr Cogn Disord.2008;25(2):135-43.

[41] Hachinski V, Iadecola C, Petersen RC, Breteler MM, Nyenhuis DL, Black SE,Powers WJ, DeCarli C, Merino JG, Kalaria RN, Vinters HV, Holtzman DM, RosenbergGA, Wallin A, Dichgans M, Marler JR, Leblanc GG. National Institute ofNeurological Disorders and Stroke-Canadian Stroke Network vascular cognitive impairment harmonization standards. Stroke. 2006 Sep;37(9):2220-41.

[42] Bohlega S, Al Shubili A, Edris A, Alreshaid A, Alkhairallah T, AlSous MW,Farah S, Abu-Amero KK. CADASIL in Arabs: clinical and genetic findings. BMC Med, Genet. 2007 Nov 9;8:67.

[43] Nilsson K, Gustafson L, Nornholm M, Hultberg B. Plasma homocysteine, apolipoprotein E status and vascular disease in elderly patients with mental illness. Clin Chem Lab Med. 2010;48(1):129-35.

[44] Chuang YF, Hayden KM, Norton MC, Tschanz J, Breitner JC, Welsh-Bohmer KA, Zandi PP. Association between APOE epsilon4 allele and vascular dementia: The Cache County study. Dement Geriatr Cogn Disord. 2010;29(3):248-53.

[45] Ning M, Zhang Z, Chen Z, Zhao T, Zhang D, Zhou D, Li W, Liu Y, Yang Y, Li S,He L. Genetic evidence that vascular dementia is related to Alzheimer's disease: genetic association between tau polymorphism and vascular dementia in the Chinese population. Age Ageing. 2011;40(1):125-8

[46] Qiu C,Winblad B, Fratiglioni L. The age-dependent relation of blood pressureto cognitive function and dementia. Lancet Neurol 2005;4:487-99

[47] Ninomiya T, Ohara T, Hirakawa Y, Yoshida D, Doi Y, Hata J, Kanba S, Iwaki T, Kiyohara Y. Midlife and late-life blood pressure and dementia in Japanese elderly: the hisayama study. Hypertension. 2011;58(1):22-8

[48] Sharp SI, Aarsland D, Day S, Sønnesyn H; Alzheimer's Society Vascular Dementia Systematic Review Group, Ballard C. Hypertension is a potential risk factor for vascular dementia: systematic review. Int J Geriatr Psychiatry. 2011 ;26(7):661-9.

[49] Hajjar I, Quach L, Yang F, Chaves PH, Newman AB, Mukamal K, Longstreth W Jr,Inzitari M, Lipsitz LA. Hypertension, white matter hyperintensities, and concurrent impairments in mobility, cognition, and mood: the Cardiovascular Health Study. Circulation. 2011,1;123(8):858-65

[50] Anstey KJ, Mack HA, Cherbuin N. Alcohol consumption as a risk factor for dementia and cognitive decline: meta-analysis of prospective studies. Am J Geriatr Psychiatry. $2009 ; 17(7): 542-55$

[51] Rusanen M, Kivipelto M, Quesenberry CP Jr, Zhou J, Whitmer RA. Heavy smoking in midlife and long-term risk of Alzheimer disease and vascular dementia. Arch Intern Med. 2011 28;171(4):333-9

[52] Frisardi V, Panza F, Seripa D, Imbimbo BP, Vendemiale G, Pilotto A, Solfrizzi V. Nutraceutical properties of Mediterranean diet and cognitive decline: possible underlying mechanisms. Review. J Alzheimers Dis. 2010, 1;22(3):715-40.

[53] Solfrizzi V, Panza F, Frisardi V, Seripa D, Logroscino G, Imbimbo BP, Pilotto A. Diet and Alzheimer's disease risk factors or prevention: the current evidence. Expert Rev Neurother. 2011;11(5):677-708. 


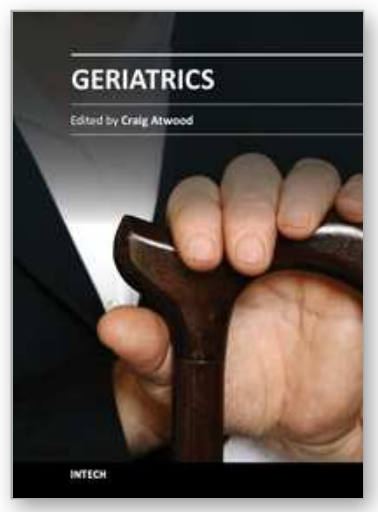

\author{
Geriatrics \\ Edited by Prof. Craig Atwood
}

ISBN 978-953-51-0080-5

Hard cover, 246 pages

Publisher InTech

Published online 24, February, 2012

Published in print edition February, 2012

With the baby boomer generation reaching 65 years of age, attention in the medical field is turning to how best to meet the needs of this rapidly approaching, large population of geriatric individuals. Geriatric healthcare by nature is multi-dimensional, involving medical, educational, social, cultural, religious and economic factors. The chapters in this book illustrate the complex interplay of these factors in the development, management and treatment of geriatric patients, and begin by examining sarcopenia, cognitive decline and dysphagia as important factors involved in frailty syndrome. This is followed by strategies to increase healthspan and lifespan, such as exercise, nutrition and immunization, as well as how physical, psychological and sociocultural changes impact learning in the elderly. The final chapters of the book examine end of life issues for geriatric patients, including effective advocacy by patients and families for responsive care, attitudes toward autonomy and legal instruments, and the cost effectiveness of new health care technologies and services.

\title{
How to reference
}

In order to correctly reference this scholarly work, feel free to copy and paste the following:

Demet Ozbabalık, Didem Arslantaş and Nese Tuncer Elmacı (2012). The Epidemiology of Vascular Dementia, Geriatrics, Prof. Craig Atwood (Ed.), ISBN: 978-953-51-0080-5, InTech, Available from: http://www.intechopen.com/books/geriatrics/the-epidemiyology-of-vascular-dementia

\section{INTECH}

open science | open minds

\author{
InTech Europe \\ University Campus STeP Ri \\ Slavka Krautzeka 83/A \\ 51000 Rijeka, Croatia \\ Phone: +385 (51) 770447 \\ Fax: +385 (51) 686166 \\ www.intechopen.com
}

\author{
InTech China \\ Unit 405, Office Block, Hotel Equatorial Shanghai \\ No.65, Yan An Road (West), Shanghai, 200040, China \\ 中国上海市延安西路65号上海国际贵都大饭店办公楼405单元 \\ Phone: +86-21-62489820 \\ Fax: $+86-21-62489821$
}


(C) 2012 The Author(s). Licensee IntechOpen. This is an open access article distributed under the terms of the Creative Commons Attribution 3.0 License, which permits unrestricted use, distribution, and reproduction in any medium, provided the original work is properly cited. 